\title{
KAREL VETTERL A POČÁTKY BRNĚNSKÉHO ROZHLASOVÉHO VYSÍLÁNÍ
}

I.

Karel Vetterl se řadí mezi přední české hudební vědce a folkloristy, přesto je docela neznámá jeho životní etapa spojená s působením v brněnském rozhlase, kde se spolupodílel na vybudování základů úspěšné hudební redakce.

II.

Pro připomenutí uved’me v krátkosti alespoň základní životopisná data Karla Vetterla. Narodil se v roce 1898, v letech 1921 až 1926 byl žákem Vladimíra Helferta na Masarykově univerzitě. Úzce s ním spolupracoval mj. na vybudování Hudebního archivu Moravského muzea. V letech 1928 až 1945 pak působil v hudební redakci brněnského rozhlasu. V rozmezí let 1945 až 1948 spravoval hudební oddělení Univerzitní knihovny v Brně, kde pak byl do roku 1953 ředitelem. Od roku 1953 až do svého penzionování působil jako vědecký pracovník Ústavu etnografie a folkloristiky Československé akademie věd v Brně.

V hudebněhistorických pracích se zabýval moravskou regionalistikou, v několika zásadních statích také sociologií rozhlasu. Aktivně se podílel na reorganizaci brněnského hudebněfolkloristického pracoviště a rozvinul badatelskou činnost v řadě studií a významných edicích. Českou hudební folkloristiku zastupoval v Mezinárodní radě pro lidovou hudbu, jejích kongresů se aktivně účastnil. Krátce přednášel hudební folkloristiku na brněnské univerzitě. Zemřel v roce 1979.

\section{III.}

Nyní krátce k brněnskému rozhlasovému vysílání před nástupem Karla Vetterla. Brněnské rozhlasové studio je po Praze druhým nejstarším vysílacím pracovištěm. K vysílacím pokusům zde došlo ještě před zahájením pravidelního vysílání. 
Už v únoru 1922 se brněnské radiotelegrafní stanici podařilo odvysílat několik národních písní, které zachytily stanice v Itálii a Dánsku. V prvním roce fungování brněnského rozhlasu bylo hlavním úkolem zvládnutí technické stránky vysílání a propagace rozhlasu. První vysílací pokusy se konaly od 10. do 13. května 1924, vysílalo se prrímo z budovy vysílače v Brně Komárově. První studio bylo zrrízeno v pavilonu na střeše brněnského Zemského domu a zahájilo provoz 1. záríí 1924. Ředitelem stanice se stal Jan Čermák, který současně vykonával funkci redaktora, technika i hlasatele. Čermák brzy přizval ke spolupráci profesora brněnské konzervatoře Ladislava Malého a pověril ho tvorbou hudebního programu. Díky jeho kontaktům se na rozhlasových pořadech podíleli hlavně profesoři a žáci brněnské konzervatoře, stejně jako členové brněnského Národního divadla.

Koncem roku 1925 z rozhlasu Ladislav Malý odešel, hudebního oddělení se po jeho odchodu ujal Jan Janota, dirigent orchestru Národního divadla v Brně. Dramaturgii zaměřil po dohodě s pražskými kolegy zejména na předromantickou hudbu a soudobou hudbu moravskou. Od 14. listopadu 1925 se už vysílalo z moderního ateliéru v Nové ulici číslo 18 (dnešní Lidická), kde bylo zř́zeno první akusticky vybavené studio. $\mathrm{V}$ této době byl už vypracován rámcový program, podle něhož se třikrát týdně vysílal hodinový orchestrální koncert a pravidelné večery operetní hudby. Operní večery byly doménou členů opery brněnského Národního divadla. Péče byla věnována také lidové písni.

Polovina dvacátých let 20 . století byla pro rozhlas dobou neobyčejného rozmachu. Přibývali noví koncesionáři, konečně byly peníze na investice do nového technického zařízení, na zaplacení drahých přenosů. Rozhlas se v krátké době stal běžnou součástí denního života.

V roce 1925 se stal novým správcem brněnské odbočky a následně ředitelem Antonín Slavík, který pověril hudební stránkou brněnského vysílání Vladimíra Šimáčka. Rozhlasového orchestru se ujali Jan Janota a Břetislav Bakala. Základem programu byla i nadále hudba, nejvíce prostoru zaujímala hudba komorní. Profesoři brněnské konzervatoře iniciovali nejrůznější komorní sestavy, z nichž mnohé začaly s rozhlasem spolupracovat. Nedílnou součástí hudebního vysílání byly přímé přenosy z brněnského Národního divadla. Přistoupilo se i k vysílání operet, o které posluchači projevili nebývalý zájem. V nedělních matiné byla vysílána duchovní hudba a symfonické koncerty orchestru brněnského Národního divadla.

\section{IV.}

V roce 1926 ukončil Karel Vetterl svá univerzitní studia. Ochrannou ruku nad ním držel jeho učitel Vladimír Helfert, který si plně uvědomoval jeho výjimečné nadání a předpoklady pro muzikologickou práci. Př́ležitostí pro zaměstnání v hudebněvědném oboru však nebylo v Brně mnoho, proto zaměřil Vetterl svou pozornost (mj. na Helfertovo doporučení) právě k brněnskému rozhlasu. První kontakt s brněnským rozhlasem navázal nejprve prostřednictvím rozhlasového orchestru, kde začínal jako výpomocný houslista bez pevného angažmá v roce 
1927. 1. ledna 1928 nastoupil pak do zaměstnaneckého poměru jako programový úředník - hudební redaktor a dramaturg. Hned vzápětí však začalo vedení rozhlasu uvažovat o Vetterlově přesunu mimo Brno, proto žádal Vetterl o úpravu své pracovní smlouvy $\mathrm{v}$ tom smyslu, že mu bude garantováno pracovní zařazení $\mathrm{v}$ oblasti rozhlasového programu s místem působení v Brně. Svoji žádost odůvodnil takto: ,[...] v Brnějsem vyrostl, zde studoval, jsem v živém kontaktu s mistni univerzitou, knihovnami, archivy a všemi kulturními činiteli, udržuji přimý styk s moravskými zámky, po ukončeni univerzitnich studií pracuji dále vědecky v oboru kulturni (hudebni) historie moravské a této kulturni práci na Moravě chci zasvětit svuij život." Obratem byl ubezpečen ředitelstvím, že s ním na jiné místo není počítáno.

Na přelomu dvacátých a třicátých let bylo Brno pověřováno vysíláním především starší hudby a hudby zábavné. Hlavním těžištěm hudební činnosti byly pořady populární hudby, pravidelné orchestrální koncerty, folkloristické pořady. Pozornost byla věnována české hudbě se zvláštním zřetelem $\mathrm{k}$ hudbě moravských skladatelů. O sborovou tvorbu pečovalo především Pěvecké sdružení moravských učitelů a pěvecké sdružení Opus. Pevnou součástí programu se staly Lidové orchestrální koncerty, které se pravidelně začaly vysílat od roku 1935. Při přenosech oper a koncertů se v souladu s rozhlasovými zásadami zpravidla uvádělo jen jedno jednání nebo část představení. Brněnský rozhlasový orchestr měl už 35 stálých členů. Účinkoval až pětkrát týdně v samostatných rozhlasových pořadech. $\mathrm{V}$ oboru lidové písně a folkloru se Brno zaměřilo na ucelené pořady ze Slovácka, Valašska, Hané, Horácka a moravsko-slovenského pomezí. Autentický folklór se postupně nahrazoval stylizovanými formami.

Hudební problematice se věnovalo též německé vysílání brněnského rozhlasu: prezentovaly se zvláště díla a výkony německých hudebních umělců z českých zemí a tvorbu programu ovlivňovali činitelé jako Paul Nettl, Hans Holländer a další, Karel Vetterl na řadě projektů německého vysílání rovněž spolupracoval.

V brněnském rozhlase dosáhl Vetterl rychlého pracovního postupu: k 1. srpnu 1931 byl jmenován šéfem hudebního programu, $v$ této funkci setrval až do 28. června 1940, kdy byl pověřen funkcí správce celé brněnské pobočky a současně vykonával dál funkci šéfa hudebního oddělení. 9. dubna 1941 byl pak Karel Vetterl jmenován ředitelem brněnské odbočky.

19. března 1942 vystř́dal Vetterla ve funkci ředitele Němec Emil Stepan. 22. ř́jina 1942 byl Karel Vetterl opět jmenován vedoucím hudebního oddělení. V čase jeho ředitelské funkce řídil hudební redakci Čeněk Gardavský.

Po skončení druhé světové války začala mít v rozhlase hlavní slovo revoluční Závodní rada, která začala brzy vést tažení proti Karlu Vetterlovi, důvodem byla pravděpodobně osobní msta některých jeho bývalých podřízených. Pro dokreslení situace citujme např́klad dopis z 21. srpna 1945:

„Závodni rada se usnesla na tomto rozhodnutí:

Kolektivní morálka zaměstnancủ podniku je jedním z nejdůležitějšich předpokladů kladné a radostné budovatelské práce. Máme váżné důvody predpokládat, že Vaše setrvání v pracovním společenství brněnského rozhlasu by tuto kolektivní 
morálku vážně ohrozilo. Jako důvod uvádíme především hromadný veřejný odmítavý postoj členů orchestru, kněmuž se připojili také mnozí zaměstnanci ostatních oddělení. Po stránce národni spolehlivosti nebylo proti Vám námitek. Toto usnesení sdělujeme reditelství podniku.“"

30. zář́ 1945 dopisem sděloval Karel Vetterl vedení rozhlasu, že si není vědom žádného provinění, z důvodu kterého by měl být degradovován, ani neví, čím byl motivován „odmítavý“ postoj brněnských rozhlasových zaměstnanců, kteří proti němu podepisovali petici. Přesto 19. října 1945 odmítnul návrh na přeřazení mimo Brno a na podřadnější funkci, raději přijal výpověd', která byla formálně datovaná až k 30. červnu 1946. Takto poněkud smutně končí životní etapa Karla Vetterla $\mathrm{v}$ brněnském rozhlase.

\section{V.}

Pokusme se nyní v krátkosti shrnout Vetterlovu rozhlasovou činnost. Už v sezóně 1928/1929 zavedl Karel Vetterl do brněnského vysílání první tzv. „historické večery“ věnované určitým historickým obdobím v dějinách hudby (např́klad hudbě rokokové, hudbě období francouzské revoluce, duchovní hudbě 18. století, české obrozenecké písni, mozartovské hudbě ad.); tyto večery byly vždy zahajovány odborným teoretickým výkladem. V ř́ijnu 1930 tak např́klad provázel pořad s názvem Večer na jaroměřickém zámku okolo roku 1790 Vetterlův učitel Vladimír Helfert. Na dalších pořadech tohoto typu se později podíleli mimo Helferta také Ludvík Kundera, Jan Racek, Gracian Černušák aj. Od roku 1930 Vetterl mistrně kombinoval hudbu a slovo v rozhlasových pořadech na dané téma, uved’me zejména jeho úspěšný pořad Halali. Lovecký obraz z motivů literárnich a hudebních. V řadě těchto pásem se velmi dobře uplatnila literární kvalifikace jeho blízkého spolupracovníka, rozhlasového redaktora Dalibora Chalupy, proto tento typ literárně hudebních pásem v Brně nadlouho zdomácněl.

Karel Vetterl neomezoval svůj zájem pouze na hudbu umělou, pozornost věnoval také tvorbě lidové, od tematických koncertních pořadů prováděných lidovými zpěváky a národopisnými kroužky v rozhlasovém studiu až k reportážní prezentaci př́mo v terénu, takto byla např́klad zachycena Národopisná reportáž ve Velké. Přesto pražské vedení rozhlasu nemělo vždy pro tyto pořady pochopení, ředitel Ladislav Šourek např́íklad žádal ihned zavést níže uvedené opatření požadované v roce 1937 tehdejším předsedou vlády Milanem Hodžou, cituji: „Pan predseda vlády Dr. Milan Hodža kritisoval velmi ostře některé folkloristické programy, o nichž prohlásil, že byly př́liš lidové a že ,z titulu folkloru degradovaly uměleckou hodnotu vysiláni'. Nedoporučuje, abychom v relacich 1/4, 1/2 hodinových neb $i$ delšich, dávali zpivat chlapcům z dédiny, naopak považuje za dostatečné, když se původni folklor bude přednášeti pouze jako ukázka, nejvýše 5 minut. Doporučuje spiše pěstovat folklor zušlechtèný formou i prednesem."

Mimo folklórní pořady připravoval Vetterl také cykly pořadů věnované dětem a hudební výchově, výklad vždy doprovázely hudební ukázky (dějiny hudby, hu- 
dební formy, psychologie hudebního vnímání ad.). Tak se v pravidelné měsíční zprávě o brněnské činnosti určené pražskému vedení za měsíc únor 1936 můžeme dočíst:

„Z iniciativy dr. Vetterla zavedli jsme letos instruktivni pořady Jak se učíme s dětmi zpivat. Jsou to rozpravy s Františkem Lýskem, sbormistrem Jistebnických zpěváčků, které vede za odborníky Dr. Bohumir Štédron̆ a za laiky náš referent Dalibor Chalupa. Tyto rozpravy se netýkaji toliko teorie nácviku písni s dètmi, ale jsou doprovázeny téź praktickými ukázkami sborového zpěvu jistebnických zpěváčkü. Mimo to se zabývaji i otázkou potřeby zpěvu a úkazy, proč se dnes nezpivá tolik, jak se zpívalo dřive a jaké jsou toho príčiny."

Vetterl sám si uvědomoval nutnost postupné proměny hudební dramaturgie v rozhlasovém vysílání, když už v roce 1930 psal: „Zpočátku posluchači byli vděčni za každý tón, který se jim podařilo vylouditi z prijímacího aparátu, a vítali se stejným nadšením koncerty salonniho tria s repertoárem kavárenských hudeb jako písňové večery nebo komorni hudbu, která trvala nepretržitě dvě hodiny. Nikdo se nad tím nepozastavil. [...] Brzy se však naplnilo vakuum žádostivého slyšení, z rozhlasu vyprchalo kouzlo technického vynálezu a obecenstvo začalo jej hodnotiti jako program. Naučilo se poslouchati a vybirati dobré programy, cožje prvnim kladným výsledkem hudebniho rozhlasu." ${ }^{\text {"1 }}$

V roce 1938 vydal Karel Vetterl tiskem svoji významnou studii $K$ sociologii hudebního rozhlasu, kde analyzoval př́nosy a úskalí rozhlasového vysílání, hudba opustila vyhrazený prostor a vstoupila do domácností, pojem publikum nahrazuje pojem posluchač, místo cesty za hudební produkcí přichází hudba sama k posluchači. Rozhlas proto očekával nového posluchače s dokonalejší schopností slyšení, Vetterlovo zkoumání dokázalo ale také jinou skutečnost: „Průměrný lidový posluchač hledá $v$ hudebním rozhlasu najčastěji jasnou, melodickou notu a svižný taneční rytmus, které mu vnášejí do př́ibytku bezstarostnou náladu, uklidňuji nervy, zaháněji trudné myšlenky i dlouhou chvíli a zpř́jemňují práci. Touha po rekreaci bývá hlavní pohnutkou príjmu hudebniho rozhlasu. “2 Vetterlova analýza ukázala dvě cesty $\mathrm{k}$ řešení, jednak úpravou denní skladby programu, jednak vysíláním s hudebně výchovnými akcenty.

Velmi aktivně působil vždy Karel Vetterl na výročních programových konferencích Radiojournalu, které se konaly většinou jednou ročně na různých místech republiky a kde se za účasti ředitelství a zástupců jednotlivých poboček probíraly koncepční a dramaturgické plány na následující rok. Zajímavý je např. Vetterlem přednesený materiál na programové konferenci na Radhošti v dubnu 1934, jak uvádí dochovaný zápis:

„Dr. K. Vetterl podává statistický přehled rozhlasových pořadi̊ čsl. stanic od 1. ríjna do konce brezna.

1 VETTERL, Karel. Hudební programy v rozhlase. Radiojournal, 1930, roč. 8, č. 25, s. 1.

2 VETTERL, Karel. K sociologii hudebního rozhlasu. Musikologie I, Praha - Brno: Melantrich - Pazdírek 1938, s. 27-44. 
Nejvice populárnich a lehkých pořadi̊ hudebnich obstarává stanice košická, pak Bratislava, Moravská Ostrava, posléze Brno a nejméně Praha.

Z cizich autoru hraji se nejvice mimo Strausse tito skladatelé: Čajkovskij, Lehár, Grieg, Rossini.

Fysiognomie jednotlivých stanic:

Praha: seriosní česká hudba (Dvořák, Smetana, Fibich)

Brno: Dvořák, Šebor, Smetana, Nedbal, Čajkovskij, Fibich, Janáček a moravští autoři

Bratislava: Dvořák, Smetana, Moyzes, Nedbal, Strauss a bratislavští autoři

Mor. Ostrava: Leopold, Nedbal, Smatek, Šebestik, Tichý

Košice: Fučik, Smatek, Dvoř́k, Nedbal.

Vážné programy vlastni (ze studia) odpoledne i večer.

Praha: prìměrně 6 krát do měsíce, ze staré české hudby pouze Mysliveček a Jirovec.

Brno: prüměrně 3 krát do měsice, ze staré české hudby Benda, Stamic a Jírovec.

Bratislava: průmèrnè 3 krát do měsíce, ze staré české hudby Benda, Stamic, Filz, Jirovec, Koželuh, Vranický.

Košice: prüměrně 3 - 4 krát do měsíce, ze staré české hudby Stamic, Richter, Jirovec, Vaňhal.

M. Ostrava: prüměrně 1-2 krát do měsíce, ze staré české hudby Vranickýa Jírovec.

Přenosy koncertü:

Praha průměrně 5 krát do měsice.

Brno průmérně jednou.

Bratislava jednou.

Máme-li závěrem shrnout př́nos Karla Vetterla pro rozvoj českého rozhlasového vysílání, konstatujme, že se Vetterl stal v brněnském rozhlase v období od začátků do konce druhé světové války jednou z hlavních tvưrčích programových osobností a že z této brněnské stanice vybudoval moderní rozhlasový ústav celostátního významu, kde současně uplatnil i své schopnosti vědecké, popularizačně výchovné a organizační.

Petr Macek vystudoval hudební vědu a estetiku na Filozofické fakultě Masarykovy univerzity, kde také pedagogicky a vědecky působí, od roku 2004 jako vedoucí Ústavu hudební vědy. Odborně se zaměřuje zejména na problematiku hudební lexikografie, redakčně a autorsky se spolupodílel na Slovníku české hudebni kultury (Praha, 1997), nyní je v čele vědecké redakce Českého hudebního slovniku osob a institucí (www.ceskyhudebnislovnik.cz). Dále se zajímá o hudbu 18. a 20. století (knižní práce Franz Xaver Richter, Kroměřž 1989; František Xaver Richter, Holešov 2009; Směleji a rozhodněji za českou hudbu! Společenské vědomí české hudebni kultury 1945-1969v zrcadle dobové hudebni publicistiky, Praha 2006), o dějiny rozhlasového vysílání, o teorii a dějiny populární hudby, o využití výpočetní techniky v hudbě a hudební vědě atd. 


\begin{abstract}
:
This study recapitulates the work of Czech musicologist and folklorist Karel Vetterl (18891979) in the Brno Radio. Vetterl worked for the Brno Radio from 1927 to 1946, his career progressed from programme assistant through the manager of music programmes to the director of the whole Brno Radio. After the war he was discharged for political reasons. Vetterl, one of the first pupils of Vladimír Helfert at the Brno University and his close collaborator, became one the main names among those responsible for programme production in the Brno Radio, which he made a modern radio institution of nationwide importance.
\end{abstract}

\title{
Key words:
}

music, radio, Brno, Karel Vetterl

\section{Bibliography:}

Archiv Českého rozhlasu, Praha (osobní složka Karla Vetterla, materiály k brněnské pobočce, zápisy z programových konferencí).

JEŠUTOVÁ, Eva a kol. Od mikrofonu k posluchačům. Z osmi desetiletí českého rozhlasu. Praha, 2003.

MACEK, Petr. Rozhlasové působení Karla Vetterla. In Musicologica Brunensia. Sborník prací Filozofické fakulty brněnské univerzity. Brno: Masarykova univerzita, 2007, roč. 55, H 41, s. 83-94.

PATZAKOVÁ, Anna. Prvních deset let československého rozhlasu. Praha, 1935.

PEČMAN, Rudolf. Karel Vetterl jako hudební historik a muzikolog. In Živý odkaz Karla Vetterla, 1889-1979. Brno 1993, s. 23-36.

Soukromý archiv Vladimíra Vetterla, Brno (korespondence).

TONCROVÁ, Marta. K činnosti Karla Vetterla v brněnském Radiojournalu. In Živý odkaz Karla Vetterla, 1889-1979. Brno 1993, s. 131-137.

VETTERL, Karel. Hudební programy v rozhlase. Radiojournal, 1930, roč. 8, č. 25, s. 1.

VETTERL, Karel. K sociologii hudebního rozhlasu. Musikologie I, Praha - Brno: Melantrich Pazdírek 1938, s. 27-44.

VETTERL, Karel. Z korespondence učitele svému žákovi. In SPFFBU, H 9, 1974, s. 53-56.

VETTERL, Vladimír. Karel Vetterl a rozhlas - vzpomínky syna na otce. Národopisná revue, 1998, roč. 7, č. 3, s. 189-190. 
